\title{
Nitrožilní anestetika
}

\section{Jarmila Drábková}

Klinika anesteziologie, resuscitace a intenzivní medicíny, Oddělení následné intenzivní péče, 2. LF UK a FN Motol, Praha

Nitrožilní celková anestetika jsou stále a dominantně pojímána jako „indukční látky“, tj. přípravky, určené k úvodu do celkové anestezie. Uvedená indikace tradičně zahrnuje thiopental, propofol, etomidát a ketamin. Jejich farmakologické vlastnosti umožňují propofolu a ketaminu využití i k infuzní analgosedaci. Jsou ordinovány i mimo rámec anesteziologie, zejména v intenzivní medicíně a péči. Selektivně se využívají i možnosti alternativní, nejen nitrožilní aplikace. V současném pojetí kombinované anestezie, balancované celkové anestezie a analgosedace se k tradičním nitrožilním celkovým anestetikům těsně připojují i midazolam a dexmedetomidin s anxiolytickým a řiditelným sedativním působením. Stručný přehledný text se věnuje základním pohledům, významným pro farmakology, i výčtu jejich klinicky důležitých vlastností, účinků a vymezení.

Klíčová slova: nitrožilní anestetika, TIVA, anestezie balancovaná, analgosedace, sedace při vědomí, thiopental, propofol, etomidát, ketamin, midazolam, dexmedetomidin (Dex).

\section{Intravenous anaesthetics}

Intravenous general anaesthetics are still and predominantly perceived as "induction agents", i.e. drugs intended to induce general anaesthesia. This indication traditionally includes thiopental, propofol, etomidate, and ketamine. Their pharmacological properties allow propofol and ketamine to be used for infusion analgosedation. They are even prescribed outside the field of anaesthesiology, particularly in intensive medicine and care. Selectively, alternative options are used in addition to intravenous administration. In the current concept of combined anaesthesia, balanced general anaesthesia, and analgosedation, the traditional intravenous general anaesthetics are closely coupled with midazolam and dexmedetomidine with an anxiolytic and controllable sedative action. This brief review article deals with essential insights, relevant for pharmacologists, as well as an account of clinically important properties, effects, and delimitations.

Key words: intravenous anaesthetics, TIVA, balanced anaesthesia, analgosedation, conscious sedation, thiopental, propofol, etomidate, ketamine, midazolam, dexmedetomidine (Dex).

\section{Zkušenosti a poučení z anesteziologické historie}

Současná nitrožilní anestetika nám již ve své historii z 20. století přinesla řadu poznatků v kladném i ve velmi negativním směru. Vzdor všem peripetím jsou v soudobé anesteziologii její naprosto suverénní a integrální součástí. Dominovaly a stále dominují především v úvodu do celkové anestezie s pojmem „indukční agens". Nicméně zdaleka překročila tento hlavní indikační rámec a vytvořila i vhodné kombinace pro analgosedaci a pro sedaci při vědomí v intenzivní péči.
Původní nitrožilní prípravky různých chemických skupin s možností i odlišné biodostupnosti než jen i.v., a tím použitelné i v alternativním podání (1), se nyní osvědčují v urgentní a v intenzivní medicíně, ve vojenské medicíně, v psychiatrii, ve veterinární anesteziologii a dokonce jako diskuzní téma k eutanázii. Jsou složkami analgosedace, sedace při vědomí, mohou předcházet pooperačnímu deliriu (2) mají zřejmě vliv na imunitu a zánětlivé procesy.

Na jejich nástupní éře ve 20. století se vysoce varovně podepsal thiopental se svým snad- ným, jednoduchým i.v. podáním a s odborným nepochopením. Byl v prosinci roku 1941 rutinně užit při masových anesteziích po překvapivém válečném napadení US flotily v Pearl Harboru a stal se fatální príčinou smrti u posttraumaticky šokovaných mužů (3). Nepř́iznivé výsledky vedly dokonce $v$ armádním sboru a jeho velení ke změně doktríny volby celkové anestezie u pacientů v akutním kritickém stavu - doplnila se objemová náhrada, připojila se analgetika, doplnil se ketamin k šetrné balancované anestezii, prísně personalizovaně zvolené. 


\section{| HLAVNÍ TÉMA}

Tehdejší historický a ambivalentní účinek thiopentalu versus jednoduché podání z předplněné, standardní injekční střikačky vedl k jejich zjednodušeně výstižnému zhodnocení: „Deadly easy - easily dead", a to platí stále.

Další, mírovou historií prošla přechodně celá řada prípravků z různých chemických skupin vč. hydroxydionu, methohexitalu, propanididu, natriumhydroxybutyrátu sodného - gamma-OH. V 60. letech minulého století byly i.v. prípravky výběrově použity i v rámci tzv. neuroleptanestezie $v$ kombinaci droperidol-fenoperidin, poprr. droperidol-fentanyl, ale uvedená metoda se anesteziologicky neosvědčila.

V soudobé klinické anesteziologii se užívají chemicky, farmakologicky i indikačně čtyři prípravky v základní skupině nitrožilních anestetik: thiopental, propofol, etomidát a ketamin. Volně se k nim ze skupiny benzodiazepinů přiřazuje midazolam, oceňovaný v závislosti na dávce i pro sedaci při vědomí a laskavé amnestické účinky zejména u dětí. V poslední době několika let se v kombinacích, popř. při pooperačních neuroaxiálních blokádách osvědčuje i sedativně a vegetativně stabilizující dexmedetomidin (dále dex).

\section{Anesteziologie a i.v. anestetika současnosti}

Z pohledu na jejich klinické používání a personalizované volby se vychází z požadavků, které by u pacientů různých kategorií měl zvolený prî́pravek splnit. Nitrožilní anestetika se stále a v naprosté většině podávají k subjektivně príjjemnému a pritom pohotovému úvodu do celkové anestezie pro operační výkony a intervence různě dlouhého trvání a chirurgického stresu. Výběrově jsou vhodná i pro kombinace s opioidy i s dalšími adjuvantními př́pravky, jako jsou nedepolarizující nervosvalové blokátory - svalová relaxancia. Lze je využít k pokračující celkové anestezii, která se dále vede potentními inhalačními anestetiky; snižují jejich potřebné dávkování. V nízkém infuzním dávkování lze jimi sedativně doplnit neuroaxiální/ lokoregionální anestezii; přispívají tím ke klidu a pohodě pacienta při operačním výkonu, u něhož je účinná analgezie plně zajištěna přípravkem ze skupiny místních anestetik. Kapitoly o nitrožilních anesteticích a jim prìdružených sedativech/ hypnoticích jsou zpracovány v zahraničních (4) i v našich učebnicích anesteziologie i v přehledech léků, uživaných v České republice (5).
Požadavky v celém komplexu náležitě a vyváženě podané celkové anestezie nesplní žádné nitrožilní anestetikum v plném rozsahu. Patří k nim nároky:

- Útlum - iatrogenní ztráta vědomí různé hloubky

- Vegetativní stabilizace bez excitace a s inhibicí stresu, protektivní orgánový účin

- Snadné odbourání/eliminace bez přespávání, zejména u ambulantních a zvýšeně rizikových pacientů

- Minimalizace až absence nevhodných interakcí a nežádoucích účinků u různě medikovaných chronických pacientů, při užití mimotělního oběhu či prístrojové kontinuální náhrady renálních funkcí, při metabolické dyshomeostáze atd.

- Absence útlumu plodu při anestezii rodičky (6)

- Absence nevhodného ovlivnění neurovývoje mozku dětí do 3 let jejich věku (7)

- Možnost kontroly jejich centrálního působení cestou BIS (bispektrální index) i stanovením jejich hladin v krvi, např. při TIVA (totální intravenózní anestezii).

\section{Základní neurofyziologický pohled}

Pưvodní, jednoduché učebnicové pojetí dělí nitrožilní anestetika na asociativně a disociativně působící. Asociativně účinné přípravky tlumí vědomí a navozují bezvědomí podle velikosti podané dávky od úrovně mozkové kưry postupně descendentně až po funkce v mozkovém kmeni - tak, jak Guedel kdysi popsal stadia celkové anestezie. Jejich společnou funkcí je zřejmě inhibice GABA receptorů. Působí změnu dráždivosti neuronů, ovlivňují synaptický přenos

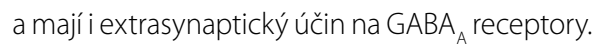
Př́pravky neúčinkují analgeticky.

Disociativní skupina je zastoupena pouze ketaminem, ten vede $\mathrm{k}$ thalamokortikální inhibici a ke stimulaci limbického systému, působí cestou NMDA receptorů. Jako jediný z celé skupiny má významnou analgetickou potenci pro somatickou bolest.

Projevy v CNS Ize sledovat peroperačně i v intenzivní péči podle EEG s vysokým rozlišením v různých oblastech mozku; klinicky se zobrazují formou BIS - jednotným bispektrálním indexem.

Jednotlivá nitrožilní anestetika nepůsobí přesto univerzálně, jednotně. Mají vliv nejen na funkce CNS, ale i na další orgány a systémy - a to s obrazem různorodých, podle dávkování až nežádoucích účinků, pravděpodobně i s vlivem na rozvíjející se mozek dětí do 3 let věku apod. CNS funkcím i širším procesům, mediátorům a markerům je věnována velmi cílená pozornost.

\section{Nitrožilní anestetika - imunitní a protizánětlivé působení}

Kromě celkově anestetického/sedativního účinku se v současné době přiznávají těmto přípravkům nezávisle na jejich farmakologické příslušnosti i protizánětlivé účinky a působnost na imunitní systém a imunitu, na systém cytokinů v celém perioperačním období i v jiném velmi závažném stavu s prvkem stresu (8). Působnost přesahuje skupinu nitrožilních anestetik a je zřejmě rưznorodý, dosud není podrobně vysvětlen.

Thiopental zřejmě inhibuje baktericidní funkci leukocytů, chemotaxi monocytů, omezuje aktivaci NF-kappa B, proliferaci lymfocytů. Po podání pouhé jednorázové úvodní dávky před dalším vedením celkové anestezie je tento vliv zřejmě zanedbatelný. Propofol omezuje funkce monocytů i neutrofilů, proliferaci polymorfonukleárů, ale pouhá indukční dávka není u imunokompetentních pacientů v tomto směru významná. Etomidát omezuje syntézu prekurzorů kortizolu, a tím i pokles koncentrace plazmatického kortizolu, nevede však k uvolnění histaminu. Jeho podání je proto striktně vymezeno na úvod do anestezie nebo pro ultrakrátké výkony u specificky indikovaných pacientů, jako jsou snadní liberátoři histaminu. Ketamin se podílí na řízení zánětlivých mediátorů, nízké dávkování omezuje v pokusech na zvíratech extravazaci albuminu, v klinické anesteziologii a v intenzivní péči snižuje uvolňování lipopolysacharidů, tvorbu superoxidů, IL-6 a CRP. Midazolam se váže na periferní receptory makrofágů, omezuje tvrobu IL-1, IL-6, TNFalfa a T buněk. Dexmedetomidin snižuje rovněž hladiny prozánětlivých cytokinů, hodnotu CRP, IL-6, IL-8, TNFalfa, stimuluje celkovou cholinergní a protizánětlivě účinnou osu v organismu.

Tyto účinky pravděpodobně nejsou klinicky významné po jednorázovém podání indukční dávky, ale mohou se projevovat v kombinaci s pokračujícími inhalačními anestetiky a při del- 
ším - infuzním užití v intenzivní péči. Definitivní poznatky z klinické anesteziologie a imunologie dosud nejsou k dispozici, ale stále se intenzivně doplňují, především s rozvojem neurofyziologie a farmakokinetiky. Specifická pozornost se věnuje i vybraným doprovodným účinkům, např. halucinogenním, riziku vzniku pooperačního deliria, jejich dávkování při připojení mimotělních podpưrných systémů, změně eliminační clearance při nízké tělesné teplotě apod.

\section{Pohled klinického farmakologa}

Klinická farmakologie zohledňuje především určující skupinovou př́slušnost nitrožilních anestetik a jejich adjuvancií, velikost jejich molekuly, rozpustnost $v$ tucích, vazbu na plazmatické bílkoviny a řadu dalších podkladů z farmakokinetiky a farmakodynamiky jednotlivých prípravků, a to predevším po jejich i.v. bolusovém podání. Údaje zahrnují nejen různé působení na mozkové funkce, ale i na další orgány a systémy. Na nich poté závisí i jejich klinické indikace a předpokládaný účinek co do intenzity a trvání, ale i jejich interakce, nežádoucí účinky a rizika.

Farmakokinetika závisí na vazbě na tucích (přestup hematoencefalickou bariérou), na vazbě na proteiny plazmy, na eliminačním $t$ 1², u infuzního podání propofolu, ketaminu, dexmedetomidinu i na jejich kontext senzitivním poločasu.

Společné údaje jsou shrnuty $\vee$ tabulkové formě (tab. 1). Charakteristická data a farmakodynamika jednotlivých prípravků, popř. specifické účinky, jsou podtrženy samostatně pro jednotlivé prípravky.

I když se jedná v zásadě o nitrožilní (v kritické nouzové situaci o analogickou intraoseální aplikaci), je možno thiopental podat i rektálně, ketamin nitrosvalově nebo nazálně; propofol, ketamin a midazolam se volí i infuzně např. v intenzivní péči. Celý proces i klinické projevy se $v$ těchto prípadech ovšem liší.

Vedení anestezie je rozčleněno: Při podávání výhradně nitrožilní anestezie (TIVA - total intravenous anaesthesia) se užívá kombinace $s$ velmi potentními opioidy. Liší se od běžné balancované anestezie, využívající doprovodná inhalační anestetika a často i nedepolarizující svalová relaxancia.

Téma je v anesteziologické praxi velmi rozvětvené, anesteziologický postup je naplánován na určitého pacienta (tailored, tar-

Tab. 1. Základnífarmakokinetické údaje

\begin{tabular}{|c|c|c|c|c|c|c|}
\hline & Thiopental & Propofol & Etomidát & Ketamin & Midazolam & Dex \\
\hline $\begin{array}{l}\text { Distribuční } \\
\text { poločas (min.) }\end{array}$ & 8,5 & 1,8 & $2-4$ & $11-16$ & $7-15$ & \\
\hline $\begin{array}{l}\text { Distribuční } \\
\text { objem } \\
\text { (l/kg t.hm) }\end{array}$ & 2,5 & $3-10$ & $2,5-4,5$ & $2,5-3,5$ & $1-1,5$ & 118 I celkem \\
\hline $\begin{array}{l}\text { Clearance } \\
\text { (ml/kg t.hm./ } \\
\mathrm{min} . \text { ) }\end{array}$ & 3,4 & $20-30$ & $18-25$ & $12-17$ & 0,9 & $\begin{array}{l}39 \text { I/hod. } \\
\text { celkem }\end{array}$ \\
\hline $\begin{array}{l}\text { t } 1 / 2 \text { elim. } \\
\text { (hod.) }\end{array}$ & 11,6 & $1,5-12,4$ & $2,6-3,5$ & $11-16$ & $2-4$ & $\begin{array}{l}6 \text { min. }-2 \\
\text { hod. }\end{array}$ \\
\hline $\begin{array}{l}\text { Vazba na bíl- } \\
\text { koviny (\%) }\end{array}$ & 80 & 98 & 75 & $10-30$ & 94 & 94 \\
\hline
\end{tabular}

Tab. 2. Základníhemodynamické pưsobení i.v. anestetik

\begin{tabular}{|l|c|c|c|}
\hline Přípravek & MAP & $\begin{array}{c}\text { Systémová cévní } \\
\text { rezistence }\end{array}$ & Venodilatace \\
\hline Thiopental & $\downarrow$ & $\downarrow \uparrow$ & + \\
\hline Propofol & $\downarrow \downarrow$ & $\downarrow \downarrow$ & 0 \\
\hline Etomidát & 0 & 0 & 0 \\
\hline Ketamin & $\uparrow \uparrow$ & $\uparrow / \downarrow$ & +- \\
\hline Midazolam & $0 / \downarrow$ & $\downarrow / 0$ & 0 \\
\hline Dex & $\uparrow \downarrow$ & $\uparrow \downarrow$ & + \\
\hline
\end{tabular}

geted) - v jeho různorodosti - od relativně zdravého až po šokovaného polytraumatizovaného pacienta $v$ hypotermii, chronického alkoholika, pacienta s renální nedostatečností a s omezenou časovou možností předoperačního vyšetření a přípravy. Pro každého musí anesteziolog zvolit optimální strategii, přiznivou i pro operatéra.

Farmakodynamika i.v. anestetik není dosud podrobně zpracována, a to ani v detailních účincích na cílené mozkové funkce. Znalosti nyní svědčí o jejich společném útlumu cestou $\mathrm{GABA}_{\mathrm{A}}$ receptorů. Ketamin účinkuje i prostřednictvím NMDA receptorů - má analgetický vliv, může vyvolat při samostatném podání i halucinogení stav. Jeho S+ a R- enantioméry a společný racemát se vlastnostmi poněkud liší. S+ ketamin má dvakrát mohutnější plazmatickou clearance než racemický ketamin; účinek odeznívá rychleji a riziko náhlých psychomimetických halucinatorních stavů je nižší.

Barbituráty působí na AMPA a na kainátových receptorech, účinky se obecně vztahují i na glycinové a nikotinové receptory. Ovlivňují na rozhraní lipidové a proteinové vrstvy iontové kanály, ovlivňované napětím i ligandy. Jejich prípravky nemají analgetickou potenci.

Ve velkém množství nových poznatků, získaných zejména sofistikovanými zobrazovacími metodami, se hledá systém. Dosud citované teorie nejsou beze zbytku výstižné (9).
Vliv i.v. anestetik nejen na CNS, ale prioritně i na hemodynamiku a dýchání, jako zcela základní životní funkce, je nutno znát. Změny - útlum dýchání lze vyřešit ad hoc mechanicky - umělou plicní ventilací, ale změny hemodynamiky vyžadují rychlý a správně zacílený farmakologický postup. Nejdůležitější hemodynamické působení prípravků je uvedeno v tab. 2.

\section{Nitrožilní anestetika - vlastnosti a parametry}

Údaje jsou multioborově významné i v dalších literárních podrobnostech - pro kliniky, farmakology, ve vývoji prípravků, pro soudní znalce apod.

\section{Thiopental}

- Skupina: thiobarbiturát; jednorázově krátce účinný; analgezie $=0$; riziko liberace histaminu

- Indikace: i.v. úvod do celkové anestezie; alternativní možnost ovlivnění rezistentního epileptického stavu

- Kontraindikace: porfyrie, aktivní bronchiální astma

- Cave: i.m. a intraarteriální podání - vznik nekrózy!

- Vlastnosti:

- úvodní dávka: 2-5 mg/kg i.v.

- nástup účinku: < 30 s

- trvání účinku: 5-10 min. 


\section{HLAVNÍ TÉMA}

- účinná koncentrace v krvi: 10-20 g/ml

- koncentrace při probuzení: 4-8 $\mu \mathrm{g} / \mathrm{ml}$

\section{Propofol}

- Skupina: propylfenol; jednorázově krátce účinný; analgezie $=0$

- Indikace: i.v. úvod do celkové anestezie; infuzní sedace peroperačně i v intenzivní péči

- Kontraindikace: Protrahované infuzní podávání - metabolická acidóza, syndrom propofolové infuze, riziko katétrové infekce podle konkrétního prípravku a jeho vehikula

- Cave: Při probouzení riziko euforie, až amorózně zabarvené. Vzácné kazuistiky připojují s fotografiemi i riziko zezelenání vlasů vlivem specifického enzymatického vybavení jedince (Pulos B, Sviggum HP, Sharpe EE. Propofol-associated green hair discolorisation. Anesthesiology 2019; 130(3): 445).

\section{- Vlastnosti:}

- úvodní dávka: 1,5-2,5 mg/kg

- nástup účinku: 15-45 s

- trvání účinku: 5-10 min.

- účinná koncentrace v krvi: anest.: $2-6 \mu \mathrm{g} / \mathrm{ml}$ sedativní: $1-2 \mu \mathrm{g} / \mathrm{ml}$

- koncentrace prí probouzení: 1-1,5 $\mu \mathrm{g} / \mathrm{ml}$

- TIVA: 2-4-6 mg/kg/hod. - průměr

- Sedace: 25-75 $\mu \mathrm{g} / \mathrm{kg} / \mathrm{min}$.

\section{Etomidát}

- Skupina: imidazol; jednorázově krátce účinný; analgezie = 0; neuvolňuje histamin

- Indikace: i.v. úvod, monoužití pro velmi krátké výkony, snadní liberátoři histaminu

- Kontraindikace: delší nebo opakované podávání vede k supresi tvorby endogenního prekurzoru kortizolu

- Cave: velmi rychlé odeznění

- Vlastnosti:

- úvodní dávka: 0,15-0,3 mg/kg

- nástup účinku: 15-45 s

- trvání účinku: 3-12 min.

- účinná koncentrace v krvi: 300-1000 nanog/ml

- koncentrace príi probouzení: 200-350 nanog/ml

\section{Ketamin}

- Skupina: fencyklidin; $S+R$ enantiomér, samostatně nebo racemát; somaticky analgetický účin pozitivní; i.m. podání je možné; i.v. infuzní sedace je možná; kombinace s midazolamem je vhodná; hloubka vlivu na vědomí je závislá na dávce

- Indikace: výběrově přednemocniční bolestivá traumata, popálení u dospělých i dětí; obtížně zvládnutelné kritické bronchiální astma - infuze; off-label: velká deprese, rezistentní na selektivní inhibitory zpětného vychytávání serotoninu SSRI, SRNI - opakované i.v. infuze nízkých dávek

- Kontraindikace: zvýšený nitrolební, nitrooční tlak, aktivní epilepsie

- Cave: riziko halucinací a deliria prí odeznívání; S enantiomér má pravděpodobně zmírněny až potlačeny centrální účinky; v ČR je ketamin dostupný jako racemát

\section{- Vlastnosti:}

- úvodní dávka: anest.: 1-2 mg/kg i.v., 5-12 mg/kg i.m. analg.: 0,2-0,5 $\mathrm{mg} / \mathrm{kg}$ i.v.

- nástup účinku: 45-60 s po i.v. podání

- trvání účinku: 10-20 min.

- účinná koncentrace v krvi: anest.: 0,6-4 $\mu \mathrm{g} / \mathrm{ml}$ analg./sedace: 0,05-0,1 mg/kg

\section{Midazolam}

- Skupina: benzodiazepin krátce účinný; rozpustný ve vodě; analgezie při i.v. podání = 0; anxiolytický až sedativní účin podle dávky; mírný amnestický a svalově relaxační účin

- Indikace: i.v. úvod společně s opioidem; bazální infuzní sedace; kombinace s ketaminem možná

- Kontraindikace: abúzus benzodiazepinů, zhoršená kognice a mentální funkce, zejm. v pokročilém věku

- Cave: myasthenia gravis, geriatričtí a ambulantní pacienti, akutní ebrieta

\section{- Vlastnosti:}

- úvodní dávka: anest.: dospělí: 0,15-0,3 mg/kg i.v., děti: $0,2 \mathrm{mg} / \mathrm{kg}$ i.v. sedace: $0,1-1 \mu \mathrm{g} / \mathrm{ml} / \mathrm{i} . v$. infuze

- nástup účinku: 30-60 s

- trvání účinku: 15-30 min.

- účinná koncentrace v krvi: anest.: 50-200 nanog/ml sedativní: 40-100 nanog/ml

\section{Dexmedetomidin}

(dex)

- Skupina: imidazol, pravotočivý derivát medetomidinu; plný, vysoce selektivní, centrálně účinný agonista alfa2 - adrenoreceptorů s působením na mozkový kmen, locus coeruleus; účinek se nejvíce bliží fyziologickému spánku v porovnání s ostatními nitrožilními anestetiky; bifazický vliv na hemodynamiku - myokard

- Indikace: anxiolýza až rízená sedace, prevence pooperačního deliria; snížení MAC inhalačních anestetik až o 90 \%, analgetická potence, pravděpodobná orgánová protekce se snížením stresové reakce (11), omezení třesavky (10), antidotum: antagonista atipemazol, jen s užitím ve veterinární praxi

- Kontraindikace: labilní hemodynamika, četné interakce

- Cave: četné lékové inkompatibility: diazepam, amfotericin B a řada dalších prípravků, opatrnost v těhotenství, snížení při omezených jaterních a ledvinných funkcích

- Vlastnosti:

- dávkování: 0,2-0,7 $\mu \mathrm{g} / \mathrm{kg} / \mathrm{hod}$. po dobu 24 hodin

- distribuční rychlost: 6 min.

- nástup účinku: 15 minut, infuzní vrchol po 1 hod.

- kontext senzitivní t 1⁄2: 4 min. po infuzi v trvání 10 min., až 250 min. po infuzi v trvání 8 hod.

\section{Souhrn}

\section{a doporučení}

Nitrožilní anestetika jsou velmi potentní látky, působící cílený útlum vědomí. Ovlivňují významně základní životní funkce, celý lidský organismus v náročné perioperační době i v průběhu závažného, kritického stavu. Z nitrožilně podávaných celkových anestetik Ize personalizovaně zvolit nejvhodnější prípravek z pohledu stavu pacienta, rázu a trvání výkonu, intervence a začlenit jej do celkové perioperační a anesteziologické strategie nebo intenzivní péče. Kombinace a alternativní aplikace jsou výběrově možné. Bezpečnost jejich užití závisí na odborných znalostech, na reakci pacienta, na sledovaných známkách a na monitorovaných údajích. Podklady jsou dostupné z klinické farmakologie a jsou stále doplňovány novými poznatky i zkušenostmi. Jsou základem pro náležité a personalizované klinické postupy. 
HLAVNÍ TÉMA 【

NITROŽILNÍ ANESTETIKA

\section{LITERATURA}

1. Hess L, Málek J. Netradiční způsoby aplikace anestetik: možnosti jejich využití v urgentní medicíně a medicíně katastrof. Praha: Univerzita Karlova v Praze, nakladatelství Karolinum, 2016. Učební texty Univerzity Karlovy v Praze.

2. Weinstein S, et al. Postoperative delirium in total knee and hip arthroplasty patients: a study of modifiable risk factors. BJA 2018; 120(5): 412-415.

3. Crowhurst JA. The Legacy of the Anaesthesia "Events" at Pearl Harbor, 7th December 1941. Proceedings of the History of Anaesthesia Society 2015; 48: 85-95.

4. Larsen, R, Thorsten, Annecke, Fink, T. Anästhesie, 11. übe- rarbeitete Auflage; München, Elsevier; 2018; 1216 S.

5. Drábková J. Celková anestetika - Nitrožilní anestetika (indukční látky). In: Compendium. Léčiva používaná v podmínkách ČR. 5. vydání. Praha, Panax, 2018; 1200 s.

6. ACOG Statement on the FDA Warning Regarding Use of General Anesthetics and Sedation Drugs in Pregnant Women. Agoc.org [online]. December 22, 2016.

7. Davidson AJ, Sun LS. Clinical Evidence for Any Effect of Anesthesia on the Developing Brain. Anesthesiology [online]. 2018; 128(4): 840-853.

8. CruzFF, Rocco PRM, Pelosi P. Anti-Inflammatory Properties of An- esthetic Agents. In: Annual Update in Intensive Care and Emergency Medicine 2017. Springer International Publishing, 2017;401-413. 9. Roth SH, Miller KW, Orser BA, Urban BW. Unlocking the Mechanisms of Anesthesia. Anesthesia \& Analgesia [online]. 2016; 123(5): 1070-1071.

10. Kaur M, Singh PM. Current role of dexmedetomidine in clinical anesthesia and intensive care. Anesth Essays Res. 2011 Jul-Dec; 5(2): 128-133.

11. Tan JA, Ho KM. Use of dexmedetomidine as a sedative and analgesic agent in critically ill adult patiens: a meta-analysis. Intensive Care Med 2010; 36: 926-993. 